\title{
UJI EFEK KOMBINASI EEDS DAN DPW TERHADAP PENURUNAN KADAR KOLESTEROLTOTAL DAN GLUKOSA DARAH TIKUSPUTIH JANTAN HIPERKOLESTEROLEMIA- DIABETES
}

\author{
Joni Tandi ${ }^{1}$, Alpina $\mathrm{Na}^{\text {' }}{ }^{1)}$, Aprince Basilingan ${ }^{1)}$ \\ ${ }^{1)}$ Program Studi S1 Farmasi, STIFA Pelita Mas Palu \\ Email :jonitandi757@yahoo.com
}

\begin{abstract}
The study aimed to investigate the effect of combination on EEDS soursop extract ethanol and ethanol extract of EEDPW fragrant pandan leaves, lowering total cholesterol and blood glucose in male white rats induced high cholesterol and streptozotocin and did not cause toxicity in mice and determine the dose of EEDS and EEDPW leaf which effectively decreases total cholesterol and blood glucose levels in male white rats. This research is a laboratory experiment using posttest randomized controlled group design with posttest randomized control design with 8 treatment groups consisting of 5 test animals. Group 1 (normal control). group 2 (negative control) was given a NaCC Na suspension of $0.5 \% \mathrm{w} / \mathrm{v}$. Group 3 positive (simvastatin suspension) and (metformin suspension). Group 4 was given EEDS $150 \mathrm{mg} / \mathrm{kg}$ $B W$. Group 5 was given EEDPW $600 \mathrm{mg} / \mathrm{kg} \mathrm{BW}$. Group 6 was given a combination of (I) EEDS, EEDPW $150+600 \mathrm{mg} / \mathrm{kg} \mathrm{BW}$. Group 7 was given a combination of (II) EEDS, EEDPW $75+300 \mathrm{mg} / \mathrm{kg} \mathrm{BW}$. The results showed that; there is a secondary metabolite compound in soursop leaf extract and pandan wangi, EEDS combination, EEDPW can decrease total cholesterol and blood glucose level, the most effective dose in decreasing the concentration of soursop leaves leaf sole $150 \mathrm{mg} / \mathrm{kg} \mathrm{BW}$. While the most effective dose is a combination (II) EEDS and EEDPW with a dose of $75+300 \mathrm{mg} / \mathrm{kg} \mathrm{BW}$, giving the maximum effect on decreased blood glucose levels.
\end{abstract}

Keywords:High Cholesterol Feed, Streptozotocin, Annona muricata L, Pandanus amarylifollius Roxb, Total Cholesterol

\begin{abstract}
ABSTRAK
Penelitian bertujuan untuk mengetahui efekkombinasi pada ekstraketanol daun sirsak EEDS dan ekstrak etanol daun pandan wangi EEDPW, penurunkan kadar kolesterol total danglukosa darah tikus putih jantan yang diinduksi pakan tinggi kolesterol dan streptozotocin dan tidak menimbulkan toksisitas pada tikus dan menentukan dosis berapa EEDS dan daun EEDPW yang efektif menurunkan kadar kolesterol total dan glukosa darah pada tikus putih jantan. Penelitian ini merupakan eksperimen laboratorium dengan menggunakan rancangan penelitian modifikasi posttest randomized controlled group design dengan 8 kelompok perlakuan yang terdiri dari 5 ekor hewan uji. Kelompok 1(kontrol normal) dan kelompok 2 (kontrol negatif) diberi suspensi Na CMC $0,5 \%$ b/v. Kelompok 3 kontrol positif (suspensi simvastatin) dan (suspensi metformin). Kelompok 4 diberiEEDS $150 \mathrm{mg} / \mathrm{kg}$ BB. Kelompok 5 diberiEEDPW $600 \mathrm{mg} / \mathrm{kg}$ BB. Kelompok 6 diberi kombinasi (I) EEDS, EEDPW 150+600 $\mathrm{mg} / \mathrm{kg}$ BB. Kelompok 7 diberi kombinasi (II) EEDS, EEDPW $75+300 \mathrm{mg} / \mathrm{kg}$ BB. Hasil penelitian menunjukkan bahwa;terdapat senyawa metabolit sekunder pada ekstrak daun sirsak dan pandan wangi,pemberian kombinasi EEDS, EEDPWdapat menurunkan kadar kolesterol
\end{abstract}



total dan kadar gluosa darah, dosis yang paling efektif dalam penurunan kadar koleserol daun sirsak dosis tunggal $150 \mathrm{mg} / \mathrm{kg}$ BB.Sedangkan dosis paling efektif adalah kombinasi (II) EEDS dan EEDPW dengan dosis $75+300 \mathrm{mg} / \mathrm{kg} \mathrm{BB}$, memberikan efek maksimal terhadap penurunan kadar glukosa darah.

Kata Kunci : Pakan Tinggi Kolesterol, Streptozotocin, Annona muricata L,Pandanus amarylifollius Roxb, Kolesterol Total 


\section{PENDAHULUAN}

Kolesterol merupakan molekul yang berperan penting dalam sintesis membran sel, prekusor sintesis hormon steroid, hormon korteks adrenal, sintesis asam-asam empedu dan vitamin D. Kolesterol terdiri atas high density lipoprotein (HDL), low density lipoprotein (LDL) dan trigliserida (Corwin, E. J. 2009). Kadar kolesterol yang tinggi dalam darah atau hiperkolesterolemia dapat menyebabkan aterosklerosis. Kolesterol, lemak dan substansi lainnya menyebabkan penebalan pada dinding pembuluh darah arteri sehingga pembuluh darah tersebut menyempit, proses ini disebut aterosklerosis. Penyempitan pembuluh darah menyebabkan aliran darah menjadi lambat bahkan dapat tersumbat sehingga aliran darah pada pembuluh darah koroner yang fungsinya memberikan oksigen ke jantung berkurang.Proses inilah yang menyebabkan terjadinya penyakit jantung koroner (Guyton dan Hall 2008). Menurut WHO (World Health Organization) tahun 2016 sekitar 17,5 juta atau setara $31 \%$ orang meninggal akibat penyakit kardiovaskuler dan diperkirakan 7,4 juta kematian akibat penyakit jantung koroner (WHO.2016).
DM adalah suatu penyakit yang disebabkan oleh adanya gangguan menahun terutama pada sistem metabolisme karbohidrat, lemak, dan juga protein dalam tubuh. Penyakit ini membutuhkan perhatian dan perawatan medis dalam waktu lama baik untuk mencegah komplikasi. Gangguan metabolisme merupakan salah satu dampak dari akibat kurangnya insulin, yang diperlukan dalam proses pengubahan gula menjadi tenaga serta sintesis lemak (Trihono. 2013). DM yang merupakan penyakit genetik atau disebabkan keturunan disebut DM tipe 1 dan yang disebabkan gaya hidup disebut DM tipe 2. Gaya hidup yang tidak sehat menjadi pemicu utama meningkatnya prevalensi DM, jika dicermati ternyata orang-orang yang obesitas mempunyai resiko terkena DM lebih besar dari yang tidak obesitas. Berbagai penelitian epidemiologi menunjukkan adanya kecenderungan peningkatan angka insidensi dan prevalensi DM tipe 2 (Depkes 2005).

Menurut World Health Organization (WHO) tahun 2016, diperkirakan 422 juta orang dewasa di seluruh dunia hidup dengan penyakit diabetes pada tahun 2014 dibandingkan dengan tahun 1980 yang berjumlah 108 
juta orang, jumlah ini naik dari 4,7\% menjadi $\quad 8,5 \%$ (WHO 2016). International Diabetes Federation (IDF) tahun 2015, memperkirakan bahwa pada tahun 2040, akan ada 642 juta orang menderita diabetes, meningkat dari angka sebelumnya 415 juta orang. Negara Indonesia menempati urutan ke-7 dari 10 negara yang penduduknya hidup dengan diabetes dengan jumlah mencapai 10 juta orang(IDF 2015).

Hubungan kolesterol dan diabetes yaitu, penderita DM Tipe 2 kadar glukosa dalam darah tinggi karena berkurangnya insulin. Glukosa tersebut tidak dapat digunakan oleh sel Karena tidak dapat di ubah menjadi glukosa 6-fosfat, sehingga energi yang didapatkan oleh tubuh berasal dari penguraian lemak dan metabolisme protein yang kemudian meningkatkan pembentukan asetil koenzim A. Kolesterol merupakan sintesis dari asetil koenzim A, HMG-CoA, dan Mevalonat (Poedjiadi, A. 2005).Peningkatan konsumsi lemak sebanyak $100 \quad \mathrm{mg} / \mathrm{hari}$ dapat meningkatkan kolesterol total sebanyak 2-3 mg/dl. Keadaan ini dapat berpengaruh pada proses biosintesis kolesterol. Sintesis kolesterol dipengaruhi oleh beberapa faktor, salah satunya penurunan aktivitas $H M G K o A$ reduktase yang dapat menurunkan sintesis kolesterol (Yani, M. 2015).

Maserasi adalah proses ekstraksi yang sederhana, dengan cara merendam serbuk simplisia dalam cairan penyari selama beberapa hari dengan beberapa kali pengocokan atau pengadukan pada temperature ruangan (kamar). Cairan penyari akan menembus dinding sel dan masuk ke dalam rongga sel yang mengandung zat aktif, zat aktif akan larut dan karena adanya perbedaan konsentrasi antara larutan zat aktif di dalam sel dan di luar sel, maka larutan yang pekat didesak keluar. Peristiwa tersebut berulang sehingga terjadi keseimbangan konsentrasi antara larutan di dalam sel dan di luar sel.

Senyawa kimia yang terkandung dalam tanaman mempunyai peranan yang sangat penting bagi kesehatan termasuk fungsinya dalam pencegahan terhadap berbagai penyakit (Alawiyah Lusiana, 2007).

Tanaman sirsak (Annona muricata L) memiliki khasiat antara lain penyakit kanker, penyakit diabetes, penyakit jantung. Daun sirsak memiliki efek yang bermanfaat dalam meningkatkan aktifitas enzim 
antioksidan dan hormon insulin pada jaringan pankreas serta melindungi dan menjaga sel-sel pankreas $\beta$. Daun sirsak juga berpotensi sebagai antihipertensi, antispasmodik, obat pereda nyeri, hipoglikemik, antikanker, emetic (menyebabkan muntah), vermifuge (pembasmi cacing) (Adewole. 2006). Tanaman pandan wangi (Pandanus amarylifollius Roxb.). Khasiat pandan wangi (Pandanus amarylifollius Roxb.) antara lain mencegah rambut rontok, menghitamkan rambut, menghilangkan ketombe, lemah saraf, tidak nafsu makan, reumatik, pegal linu, sakit disertai gelisah. Daun pandan wangi sering digunakan sebagai bahan penyedap, pewangi, dan pemberi warna hijau pada masakan (Ismiyati, dkk. 2015)

\section{METODE PENELITIAN}

\section{Alat Peneltian}

Ayakan 40 mesh, batang pengaduk, bejana maserasi, blender (Nattional), corong kaca (Pyrex), cawan porselin, erlemeyer $50 \mathrm{ml}, 100 \mathrm{ml}$ (Pyrex), Gelas kimia $100 \mathrm{ml}, 1000 \mathrm{ml}$ (Pyrex), gelas ukur $25 \mathrm{ml}, \quad 100 \mathrm{ml}($ Pyrex), alat pengukur kolesterol (Mission Ultra), strip kolesterol test (Mission Ultra), glucometer (Accu chek), glukotest strip (Accu chek), Gunting (Faber castle),kandang hewan uji, kaca arloji, Labu alas bulat, labu Ukur $50 \mathrm{ml}$, $100 \mathrm{ml}, 200 \mathrm{ml}$ (Pyrex), mortir dan stamper, Penangas air (Thermostatic Water Bath), pipet tetes, Rak tabung reaksi, rotavapor (Italic), sonde oral (One Med Health Care), spuit injeksi $5 \& 10 \mathrm{ml}$ (One Med Health Care), spuit oral $10 \mathrm{ml}$ (One Med Health Care), tabung reaksi (Pyrex), Tempat air minum dan makan tikus, timbangan kasar (Lion star), timbangan analitik (Ohaus), Toples (Kigroud).

\section{Bahan penelitian}

Alkohol 70\%, Alumunium Foil (Klin pak), Aqua Destilata (Aqua), Aqua Pro Injeksi (Otsuka), asam klorida (Merck), Besi (III) klorida (Merck), Citrate-buffer saline (Natrium Sitrat, Asam Sitrat), ekstrak sirsak dan pandan wangi, etanol 96\%,eter, kertas saring, kuning telur bebek, larutan $\mathrm{FeCl} 3$, larutan Nacl 10\% (PT. Widatra Bhakti), $\mathrm{Na}-\mathrm{CMC} 0,5 \%$, pelet standar, pereaksi Drangedorff, pereaksi LiebermanBunchard, pereaksi Meyer, pereaksi Magnesium $\mathrm{P}$ (Merck), Pig oil, streptozotocin (Bioworld USA), tablet simvastatin, metformin, tissue dan tikus putih jantan.

\section{Pembuatan Pakan Tinggi Kolesterol}


Pakan tinggi kolesterol yang digunakan adalah pakan standar (70\%), pig oil (lemak babi) (20\%), dan kuning telur bebek (10\%). Pakan dibuat dengan cara memanaskan pig oil. Kemudian Telur bebek direbus hingga matang, lalu dipisahkan kuning telur dan putih telur. Pakan standar digerus hingga halus lalu dicampurkan dengan pig oil, dan kuning telur. Campuran diaduk hingga homogen kemudian dibentuk menjadi pelet. Jumlah konsumsi makanan tikus setiap harinya maksimum sebanyak 20 gram/tikus dan diberikan selama 4 minggu.

\section{Pembuatan Suspensi Metformin}

Dosis metforminpada manusia dewasa adalah $500 \mathrm{mg}$ per hari, jika dikonversi pada tikus dengan berat 200 gram adalah 0,018 mg, maka dosis metformin untuk tikus adalah $9 \mathrm{mg} / 200$ g/BB. Ditimbang serbuk tablet metformin yang setara dengan $360 \mathrm{mg}$ kemudian disuspensi dalam Na CMC 0,5\% hingga $100 \mathrm{ml}$.

\section{Pembuatan suspensi PTU (0,01\%)}

Propiltiourasil (PTU) diberikan dalam bentuk cairan suspensi. Cara pembuatan larutan propiltiourasil adalah menimbang 0,01 g propiltiourasil lalu digerus dalam lumpang kemudian disuspensikan dalam $100 \mathrm{ml}$ air.

\section{Pembuatan Larutan Streptozotocin}

Menimbang streptozotocin 0,24 g lalu dilarutkan menggunakan Citratebuffered saline, $\mathrm{pH}$ 4,5 hingga $100 \mathrm{ml}$ lalu diinduksikan pada tikus melalui intra peritoneal (ip). Dosis streptozotocin yakni $30 \mathrm{mg} / \mathrm{kg} \mathrm{BB}$.

\section{Pembuatan Suspensi Simvastatin}

Dosis simvastatin pada manusia dewasa adalah $10 \mathrm{mg}$ per hari, jika dikonversi pada tikus dengan berat 200 gram adalah 0,018 mg, maka dosis simvastatin untuk tikus adalah 0,18 $\mathrm{mg} / 200 \mathrm{~g} / \mathrm{BB}$. Ditimbang serbuk tablet simvastatin yang setara dengan 7,2 mg kemudian disuspensi dalam $\mathrm{Na} \mathrm{CMC}$ 0,5\% hingga $100 \mathrm{ml}$.

\section{Pembuatan Ekstrak Daun Sirsak Dan}

Pandan Wangi

Pembuatan ekstrak daun sirsak dan pandan wangi dilakukan dengan metode maserasi, yaitu daun sirsak dan pandan wangi yang telah diayak menggunakan ayakan mesh no. 40, ditimbang sebanyak 500 gram lalu diekstraksikan dengan menggunakan etanol $96 \%$ dengan cara maserasi selama 3 hari. Ekstrak kemudian disaring menggunakan kertas saring didapat filtrat. Ekstrak diuapkan menggunakan Rotary Vaccum evaporator pada suhu $70^{\circ} \mathrm{C}$ sampai 
volumenya menjadi $1 / 4$ dari volume awal, dan dilanjutkan dengan pengentalan yang dilakukan dengan menggunakan waterbath dengan suhu $60^{\circ} \mathrm{C}$ sampai menjadi ekstrak kental.

\section{Uji Penapisan Fitokimia}

Golongan metabolit sekunder yang diujikan meliputi uji flavonoid, alkaloid, polifenol, saponin dan tanin.

\section{Pengujian Efek Daun Sirsak Dan Pandan Wangi}

Penelitian ini menggunakan 35 ekor tikus putih jantan yang kemudian dibagi dalam 7 kelompok perlakuan. Setiap kelompok terdiri dari 5 ekor tikus putih jantan. Kemudian hewan uji diadaptasikan selama 14 hari di lingkungan tempat penelitian dan diberi pakan standar serta diberi minum ad libitum. Pada hari ke-0 setelah adaptasi tikus dipuasakan selama 16 jam, kemudian dilakukan pengukuran kadar kolesterol total darah awal serta pengukuran kadar glukosa darah awal. Darah tikus diambil melalui ekor lalu diukur menggunakan alat pengukur mission ultradan accu chek. Pada hari yang sama selain tikus kontrol normal/sehat diberikan pakan tinggi kolesterol dengan komposisi pakan (70\%), pig oil (20\%), dan kuning telur bebek (10\%) dan diberikan air yang telah dilarutkan PTU selama 4 minggu.Tikus dipuasakan semalam kemudian diukur kadar kolesterol total darah setelah pemberian pakan tinggi kolesterol. Kemudian diinduksi streptozotocin dosis yaitu $30 \mathrm{mg} / \mathrm{kg} \mathrm{BB}$ yang diberikan secara intrapertoneal. Saat injeksi tikus diposisikan menghadap kearah frontal hingga terlihat bagian abdomennya, posisi hewan terbalik, memegang tikus dengan menjepit menggunakan ibu jari dan jari telunjuk, dan ekornya dijepit diantara jari manis dan kelingking. Posisi jarum suntik sepuluh derajat dari abdomen berlawanan arah dengan kepala (arah jarum ke bagian perut). Lokasi suntikan pada bagian tengah abdomen, pada daerah yang sedikit menepi dari garis tengah agar jarum suntik tidak terkena kandung kemih dan tidak terlalu tinggi agar tidak terkena penyuntikan pada hati. Setelah induksi streptozotocin pada hari ke 35 diukur kadar glukosa darah. Kemudian selain kelompok kontrol normal/sehat tidak diberikan larutan, kontrol negatif diberikan larutan $\mathrm{Na}$ CMC $0,5 \%$, kontrol positif diberikan larutan simvastatin untuk tikus kolesterol dan diberikan larutan metformin untuk tikus DM. Selanjutnya kelompok ekstrak etanol daun sirsak 
dosis tunggal $150 \mathrm{mg} / \mathrm{kg} \mathrm{BB}$, ekstrak etanol daun pandan wangi dosis tunggal $600 \mathrm{mg} / \mathrm{kg}$ BB, kombinasi I sirsak 150 $\mathrm{mg} / \mathrm{kg}$ BB dan pandan wangi $600 \mathrm{mg} / \mathrm{kg}$ BB. Kombinasi II sirsak $75 \mathrm{mg} / \mathrm{kg}$ BB dan pandan wangi $300 \mathrm{mg} / \mathrm{kg} \mathrm{BB}$, kemudian pada hari ke 42 dan 49 diukur kadar kolesterol total dan kadar glukosa darah. Data hasil pengukuran kadar kolesterol total dan glukosa darah sebelum dan setelah perlakuan yang diperoleh dicatat, dianalisis dan dibuat pembahasan.

\section{Penentuan Kadar Kolesterol Darah}

Kadar kolesteroldan glukosa darah diukur dengan menggunakan alat Mission ultra dan Accu Chek. Darah diambil melalui ujung ekor tikus yang sebelumnya dibersihkan dengan alkohol $70 \%$ dan ekor tikus dibasahi dengan air hangat tujuannya untuk vasodilatasi pembuluh darah. Kemudian ekor tikus diurut perlahan-lahan kemudian ditusuk dengan jarum kecil.
Darah yang keluar diteteskan pada stik kolesteroldan stik glukometer yang sudah terhubung dengan alat kolesterol, dibiarkan selama 10 detik akan dibaca skala yang terlihat pada layar, dimana satuan skala pengukuran yang terbaca mg/dl. Pengukuran kadar kolesterol total dan glukosa darah dilakukan 4 kali yaitu, sebelum diinduksi, setelah induksi pakan tinggi kolesterol dan streptozotocin, setelah perlakuan pada hari ke 42 dan 49.

\section{Analisis Data}

Data yang diperoleh berupa penurunan kadarkolesteroldan kadar glukosa darah. Analisis secara statistik menggunakan analisis one way ANOVA, pada tingkat kepercayaan 95\% dan untuk melihat perbedaan yang bermakna antar perlakuan digunakan uji lanjut Post hoc LSD. Data dianalisis menggunakan program SPSS 23.

Tabel 1.Hasil uji Fitokimia ekstrak etanoldaun sirsak dan daun pandan wangi

\begin{tabular}{lll}
\hline \multicolumn{1}{c}{ Jenis uji } & Sirsak & Hasil \\
& Positif $(+)$ & Pandan wangi \\
\hline Uji Alkaloid & Positif $(+)$ & Positif $(+)$ \\
Uji Flavonoid & Positif $(+)$ & Positif $(+)$ \\
Uji Polifenol & Positif $(+)$ & Positif $(+)$ \\
Uji Saponin & Positif $(+)$ & Positif $(+)$ \\
Uji Tanin & & Positif $(+)$ \\
\hline
\end{tabular}


Keterangan : $(+)$ : mengandung golongan senyawa yang diuji

(-) :tidak mengandung golongan senyawa yang diuji

Tabel 2. Rerata Kadar Kolesterol Darah (mg/dl)Kadar Kolesterol Darah Tikus Putih Jantan (Rattus norvegicus) Yang Di Induksi Pakan Tinggi Kolesterol Dan Streptozotocin dan Setelah Pemberian Ekstrak Daun Sirsak Dan Pandan Wangi

Rerata \pm SD Kadar Kolesterol Total Darah (mg/dL)

\begin{tabular}{|c|c|c|c|c|c|c|c|c|}
\hline $\begin{array}{l}\mathrm{Ha} \\
\text { ri } \\
\text { ke- }\end{array}$ & $\begin{array}{c}\text { Kontr } \\
\text { ol } \\
\text { sehat }\end{array}$ & $\begin{array}{l}\text { Kontro } \\
1 \text { sakit }\end{array}$ & $\begin{array}{c}\text { Kontro } \\
1 \\
\text { positif } \\
\text { (Simva } \\
\text { statin) }\end{array}$ & $\begin{array}{c}\text { Sirsak } \\
150 \\
\mathrm{mg} / \mathrm{kg} \\
\mathrm{BB}\end{array}$ & $\begin{array}{c}\text { P W } \\
600 \\
\mathrm{mg} / \mathrm{kg} \\
\mathrm{BB}\end{array}$ & $\begin{array}{c}\text { Kombi } \\
\text { nasi I } \\
150 \text { dan } \\
600 \\
\text { mg/kg } \\
\text { BB }\end{array}$ & $\begin{array}{c}\text { Kombi } \\
\text { nasi II } \\
75 \text { dan } \\
300 \\
\mathrm{mg} / \mathrm{kg} \\
\mathrm{BB}\end{array}$ & $\mathrm{p}$ \\
\hline 0 & $\begin{array}{l}107 \pm \\
7,745\end{array}$ & $\begin{array}{c}106,6 \pm \\
8,861\end{array}$ & $\begin{array}{c}108 \pm 9, \\
380\end{array}$ & $\begin{array}{c}111,2 \pm \\
10,30\end{array}$ & $\begin{array}{c}111,6 \pm \\
11,63\end{array}$ & $\begin{array}{c}108,4 \pm \\
11,12\end{array}$ & $\begin{array}{c}109,8 \pm \\
9,620\end{array}$ & $\begin{array}{c}0,95 \\
8\end{array}$ \\
\hline 35 & $\begin{array}{c}116 \\
\pm 3,74 \\
1\end{array}$ & $\begin{array}{c}273 \pm 16 \\
, 38\end{array}$ & $\begin{array}{c}275,6 \pm \\
15,70\end{array}$ & $\begin{array}{c}298,6 \pm \\
25,00\end{array}$ & $\begin{array}{c}269,4 \pm \\
24,88\end{array}$ & $\begin{array}{c}282,4 \pm \\
25,46\end{array}$ & $\begin{array}{c}295,6 \pm \\
27,22\end{array}$ & $\begin{array}{c}0,00 \\
0\end{array}$ \\
\hline 42 & $\begin{array}{c}114,2 \\
\pm 11,5 \\
5\end{array}$ & $\begin{array}{c}270,4 \pm \\
14,31\end{array}$ & $\begin{array}{c}159,2 \pm \\
16,0\end{array}$ & $\begin{array}{c}225 \pm 73 \\
, 53\end{array}$ & $\begin{array}{c}252,4 \pm \\
32,67\end{array}$ & $\begin{array}{c}198,4 \pm \\
34,30\end{array}$ & $\begin{array}{c}234,8 \pm \\
48,12\end{array}$ & $\begin{array}{c}0,00 \\
0\end{array}$ \\
\hline 49 & $\begin{array}{c}112,8 \\
\pm 3,54 \\
4\end{array}$ & $\begin{array}{c}268,6 \pm \\
13,12\end{array}$ & $\begin{array}{c}129,8 \pm \\
6,939\end{array}$ & $\begin{array}{c}161,4 \pm \\
32,30\end{array}$ & $\begin{array}{c}206 \pm 34 \\
, 22\end{array}$ & $\begin{array}{c}134,2 \pm \\
17,63\end{array}$ & $\begin{array}{c}179,4 \pm \\
62,20\end{array}$ & $\begin{array}{c}0,00 \\
0\end{array}$ \\
\hline
\end{tabular}


Tabel. 3 Rerata Kadar Glukosa Darah Tikus Putih Jantan (Rattus norvegicus)

Yang Di Induksi Pakan Tinggi Kolesterol Dan Streptozotocin dan Setelah Pemberian Ekstrak Daun Sirsak Dan Pandan Wangi

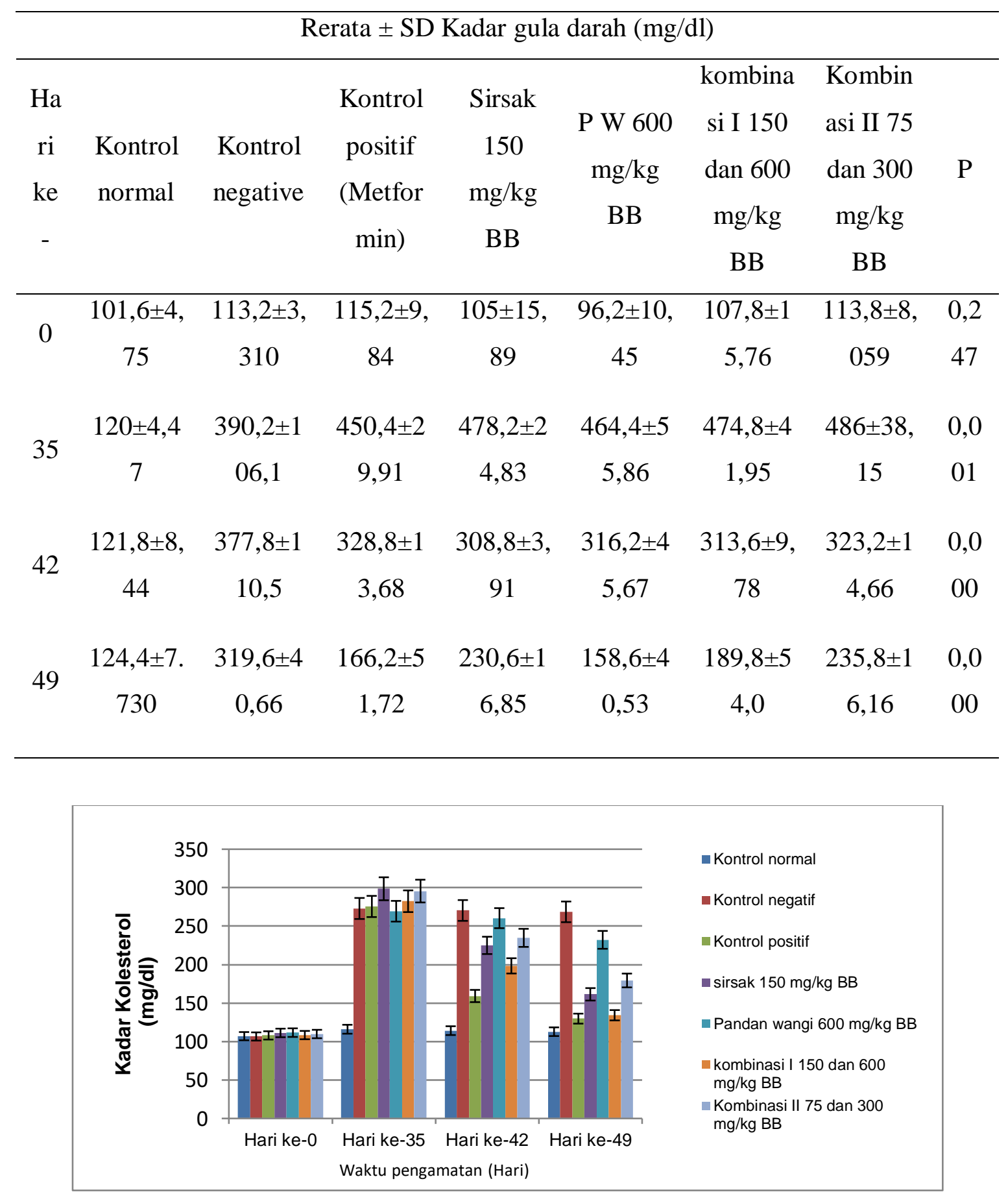

Gambar 1. Grafik Hasil Pengukuran Kadar Kolesterol Total 


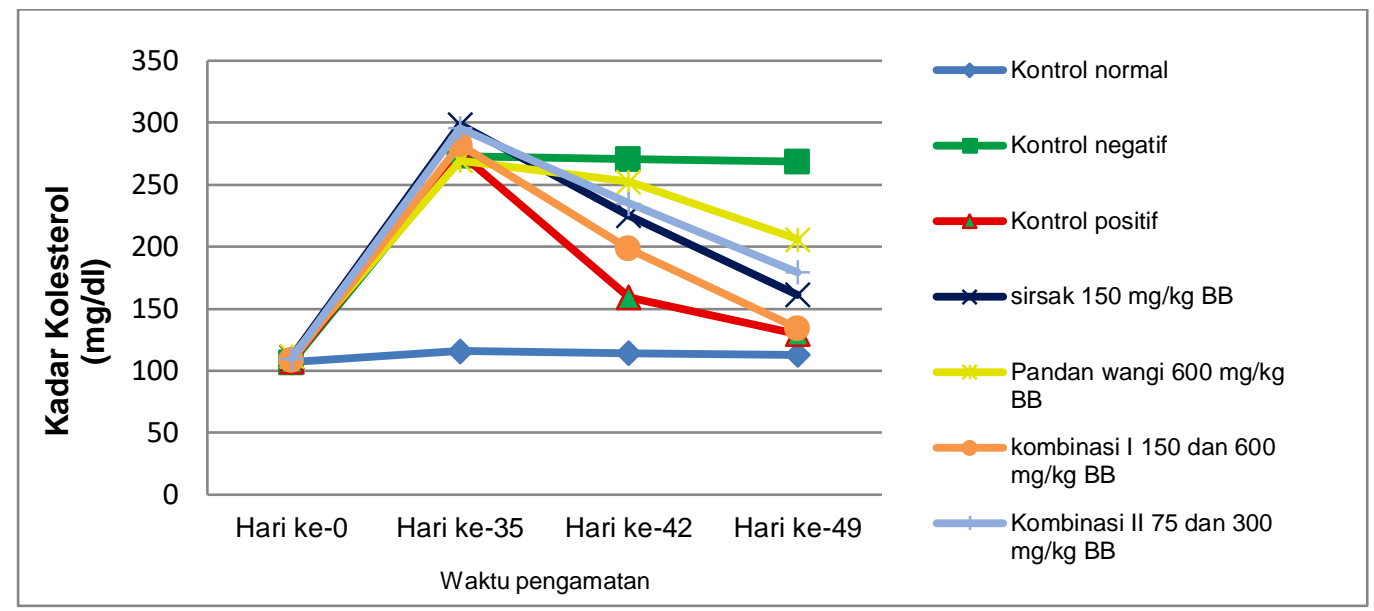

Gambar 2. Grafik Profil Kadar Kolesterol Total Hari Ke-0, Setelah Induksi, Dan Selama Perlakuan Hari Ke-42 Dan 49

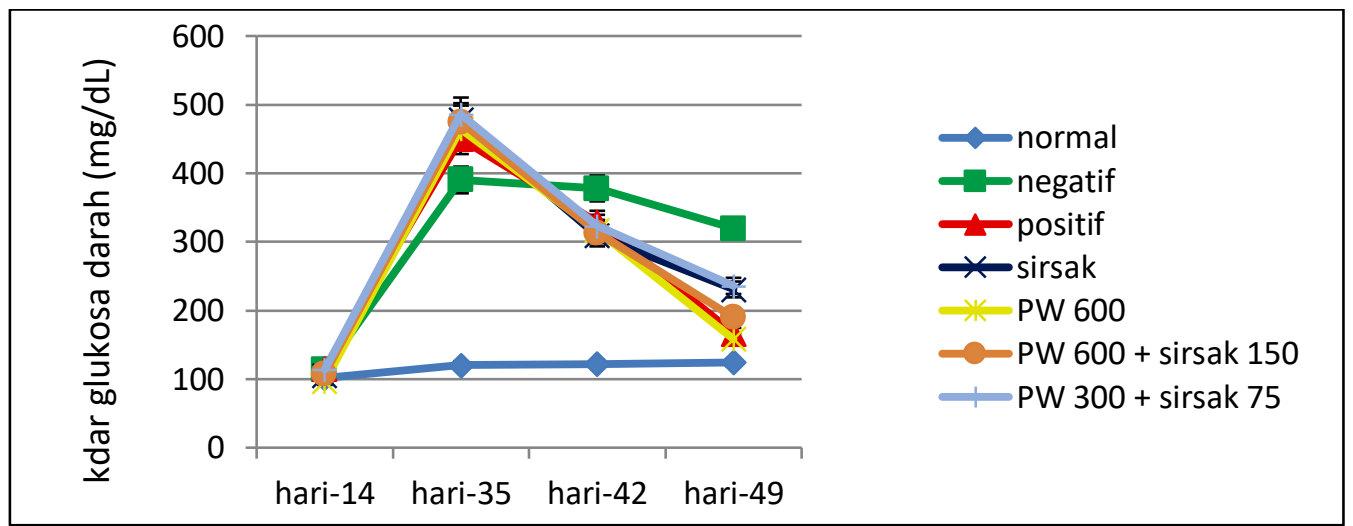

Gambar 3. Grafik Profil kadar gula darah hari ke-0, setelah induksi, dan selama perlakuan hari ke-42 dan hari ke-49.

\section{PEMBAHASAN}

Penelitian ini mengunakan tanaman Sirsak (Annona muricataL) dan pandan wangi (Pandanus amarylifollius Roxb), dengan mengambil bagian tanaman sebagai sampel penelitian adalah daun. Sampel penelitian diperoleh dari desa Tombi, Kecamatan Ampibabo, Kabupaten Parigi Moutong kelurahan, Sulawesi
Tengah. Tanaman ini dilakukan Identifikasi di UPT. Sumber Daya Hayati Universitas Tadulako Sulawesi Tengah. Hasil idetifikasi membuktikan bahwa tanaman yang digunakan dalam penelitian benar adalah spesies Annona muricataL, Pandanus amarylifollius Roxb dan suku annonaceae, pandanaceae.

Kolesterol juga sebagai produk 
metabolisme hewan yang terdapat di dalam makanan yang berasal dari hewan, misalnya kuning telur, daging, hati dan otak. Kolesterol yang ada dalam tubuh berasal dari makanan (eksogen) dan sintesis (endogen).Diabetes melitus (DM) adalah merupakan salah satu penyakit degeneratif atau penyakit tidak menular yang akan meningkat jumlahnya di masa yang akan datang. Penyakit ini muncul ketika insulin tidak cukup diproduksi atau insulin tidak dapat berfungsi dengan baik (Oktaria. 2013). Diabetes Melitus menyebabkan morbiditas dan mortalitas yang tinggi, terutama karena komplikasi vaskularnya. Luasnya komplikasi pada Diabetes Melitus tampaknya berkorelasi dengan konsentrasi glukosa darah sehingga glukosa berlebih diduga menjadi penyebab utama kerusakan sel beta pankreas (Setyaningsih,D.2008). Pankreas merupakan organ kelenjar penting dalam tubuh yang terdiri dari jaringan eksokrin dan endokrin (Mosaad. 2004).

Penelitian ini diawali dengan pengukuran kadar kolesterol dan kadar glukosa darah awal (hari-0) untuk mengetahui kadar kolesterol sebelum perlakuan. Pada hari ke-0, diperoleh data rerata kadar kolesterol total darah untuk kelompok normal; kelompok negatif; kelompok positif; kelompok ekstrak daun sirsak dosis $150 \mathrm{mg} / \mathrm{kg}$ BB; kelompok ekstrak daun pandan wangi dosis $600 \mathrm{mg} / \mathrm{kg} \mathrm{BB}$; kelompok ekstrak dosis kombinasi (I); kelompok ekstrak dosis kombinasi (II); berturutturut adalah 107; 106,8; 108; 111,2; 111,6; 108,4, 109,8 mg/dLdan 101,6; 113,$2 ; 115,2 ; 105 ; 96,2 ; 107,8 ; 113,8$ $\mathrm{mg} / \mathrm{dL}$ yang menandakan kadar kolesteroldan glukosa darah awal tikus putih jantan berada pada nilai normal yaitu $<200 \mathrm{mg} / \mathrm{dL}$. Hasil uji statistik one way ANOVA semua kelompok menunjukkan perbedaan yang tidak signifikan pada kadar kolesterol dan glukosa darah tikus putih jantan dengan nilai probabilitas adalah 0,247 dan ... (p $>0,05)$. Hal ini menunjukkan bahwa kadar kolesterol darah semua hewan uji pada awal penelitian dalam keadaan homogen.

Hari ke-35, diperoleh data rerata kadar kolesterol dan glukosa darah untuk kelompok normal; kelompok negatif; kelompok positif; kelompok ekstrak daun sirsak dosis $150 \mathrm{mg} / \mathrm{kg}$ BB; kelompok ekstrak daun pandan wangi dosis $600 \mathrm{mg} / \mathrm{kg}$ BB; kelompok ekstrak dosis kombinasi (I); kelompok 
ekstrak dosis kombinasi (II); berturutturut adalah 116; 273; 275,6; 298,6; 269,4; 282,4; 295,6 mg/dL dan 120; 390,$2 ; 450,4 ; 478,2 ; 464,4 ; 478,8 ; 486$ mg/dLyang menunjukkan kadar kolesteroltotal dan glukosa darah kelompok positif, kelompok negatif dan kelompok ekstrak lebih tinggi dibandingkan kelompok sehat. Hal ini menunjukkan bahwa kadar kolesteroldan glukosa darah pada hewan uji mengalami kenaikan kecuali kelompok sehat.

Hasil uji statistik one way ANOVA semua kelompok pada hari ke35, diperoleh nilai probabilitas kadar kolesterol dan glukosa darah adalah 0,000 dan ,,, $(\mathrm{p}<0,05)$. Hal ini menunjukkan adanya perbedaan yang signifikan terhadap kadar kolesterol total dan glukosa darah setelah pemberian perlakuan pada hari ke-35. Untuk mengetahui lebih jelas letak perbedaan yang signifikan diantara kelompok uji, maka dilanjutkan analisis data mengunakan Post Hoc Test. Hasil analisis Post Hoc Test LSD kadar kolesteroldan glukosa darah menunjukkan kelompok negatif, kelompok positif dan kelompok ekstrak berbeda signifikan dengan kelompok normal. Hal ini membuktikan bahwa terjadi kenaikan kadar kolesterol darah yang signifikan pada kelompok negatif, kelompok positif dan kelompok ekstrak setelah diberikan pakan tinggi kolesterol dan induksi streptrozotocin.

Hari ke-42, diperoleh data rerata kadar kolesterol totaldan glukosa darah untuk kelompok normal, kelompok negatif, kelompok positif kelompok ekstrak daun sirsak dosis $150 \mathrm{mg} / \mathrm{kg}$ BB; kelompok ekstrak daun pandan wangi dosis $600 \mathrm{mg} / \mathrm{kg} \mathrm{BB}$; kelompok ekstrak dosis kombinasi (I); kelompok ekstrak dosis kombinasi (II); berturutturut adalah 114,$2 ; 270,4 ; 159,2 ; 225$; 252,$4 ; 198,4 ; 234,8 \mathrm{mg} / \mathrm{dL}$ dan 121,8; 377,$8 ; 328,8 ; 308,8 ; 316,2 ; 313,6 ; 323,2$ $\mathrm{mg} / \mathrm{dL}$ yang menunjukkan bahwa kadar kolesterol darah dan kadar gluosa darah kelompok positif dan kelompok ekstrak mengalami penurunan mendekati kadar normal.

Hasil uji statistik one way ANOVA semua kelompok pada hari ke42, diperoleh nilai probabilitas kadarkolesterol dan glukosa darahadalah 0,000 dan .... $(p<0,005)$. Hal ini menunjukkan adanya perbedaan yang signifikan terhadap kadar kolesteroldan glukosa darah setelah pemberiaan perlakuan pada hari ke-42 diantara semua kelompok. Untuk 
menunjukkan lebih jelas letak perbedaan yang signifikan diantara kelompok uji, maka dilanjutkan analisis data mengunakan Post Hoc Test. Hasil analisis Post Hoc Test LSD kadar kolesterol total dan glukosa darah menunjukkan bahwa kelompok positif dan kelompok ekstrak berbeda signifikan dengan kelompok negatif dan berbeda tidak signifikan dengan kelompok normal. Hal ini menunjukkan bahwa ekstrak daun sirsak dosis 150 $\mathrm{mg} / \mathrm{kg} \mathrm{BB}$, pandan wangi dosis 600 $\mathrm{mg} / \mathrm{kg} \mathrm{BB}$, ekstrak dosis kombinasi I dan ekstrak dosis kombinasi II sudah memberikan efek terhadap penurunan kadar kolesterol darah.

Hari ke-49, diperoleh data rerata kadar kolesterol totalkadar kolesterol dan glukosa darah untuk kelompok normal, kelompok negatif, kelompok positif kelompok ekstrak daun sirsak dosis 150 mg/kg BB; kelompok ekstrak daun pandan wangi dosis $600 \mathrm{mg} / \mathrm{kg}$ BB; kelompok ekstrak dosis kombinasi (I); kelompok ekstrak dosis kombinasi (II); kadar kolesterolberturut-turut adalah112,8; 268,6;129,8; 161,4; 206; 134,$2 ; 179,4 \quad \mathrm{mg} / \mathrm{dL}$ dan kadar kolesterol berturut-turut adalah124,2; 319,$6 ; 166,2 ; 230,6 ; 158,6 ; 189,8 ; 235,8$ mg/dL yang menunjukkan bahwa kadar kolesterol total dan kadar glukosa darah kelompok positif dan kelompok perlakuan mengalami penurunan mendekati kadar normal.

Hasil uji statistik one way ANOVA semua kelompok pada hari ke49, diperoleh nilai probabilitas kadar kolesterol adalah 0,000 dan kadar glukosa darah $0,000(\mathrm{p}<0,005)$. Hal ini menunjukkan adanya perbedaan yang signifikan terhadap kadar kolesterol dan kadar glukosa darah setelah pemberiaan perlakuan pada hari ke-49 diantara semua kelompok. Untuk menunjukkan lebih jelas letak perbedaan yang signifikan diantara kelompok uji, maka dilanjutkan analisis data mengunakan Post Hoc Test. Hasil analisis Post Hoc Test LSD kadar kolesterol darah menunjukkan bahwa kelompok positif dan kelompok ekstrak daun sirsak dosis $150 \mathrm{mg} / \mathrm{kg}$ BB dan kelompok ekstrak dosis kombinasi I berbeda tidak signifikan dengan kelompok normal dan berbeda signifikan dengan kelompok negatif, kelompok ekstrak daun pandan wangi dosis $600 \mathrm{mg} / \mathrm{kg} \mathrm{BB}$, kelompok ekstrak dosis kombinasi (II). Hal ini menunjukkan bahwa ekstrak daun pandan wangi dosis $600 \mathrm{mg} / \mathrm{kg}$ BB dan ekstrakdosis kombinasi (II) $75+300$ $\mathrm{mg} / \mathrm{kg} \quad \mathrm{BB}$ belum maksimal 
memberikan efek penurunan kadar kolesterol sama dengan kelompok positif. Sedangkan ekstrak daun sirsak dosis $150 \mathrm{mg} / \mathrm{kg}$ BB, ekstrak dosis kombinasi (I) $\quad 150+600 \quad \mathrm{mg} / \mathrm{kg} \quad \mathrm{BB}$ memberikan efek terhadap penurunan kadar kolesterol darah. ekstrak daun sirsak dosis $150 \mathrm{mg} / \mathrm{kg}$ BB merupakan dosis yang efektif menurunkan kadar kolesterol darah. Hasil analisis Post Hoc Test LSD kadar glukosa darah menunjukkan bahwakelompok positif dan kelompok ekstrak berbeda signifikan dengan kelompok negatif dan berbeda tidak signifikan dengan kelompok normal. Hal ini menunjukkan bahwa ekstrak daun sirsak dan daun pandan, dosis tunggal maupun kombinasi memberikan efek terhadap penurunan kadar glukosa darah. Dilihat dari kadar glukosa darah ekstrak daun sirsak dan daun pandan wangi tunggal 1 dosis $150 \mathrm{mg} / \mathrm{kg} \mathrm{BB}$, tunggal 2 dosis $600 \mathrm{mg} / \mathrm{kg} \mathrm{BB}$, kombinasi 1 dosis 150+600 mg/kg BB, dan kombinasi 2 dosis $75 \mathrm{mg} / \mathrm{kg}+300 \mathrm{mg} / \mathrm{kg}$ BB yang masing-masing memberikan efek dengan adanya penurunan kadar glukosa darah, maka ekstrak daun sirsak dan pandan wangi tunggal 2 dosis 600 $\mathrm{mg} / \mathrm{kg} \mathrm{BB}$ dan kombinasi 2 dosis 75 $\mathrm{mg} / \mathrm{kg}+300 \mathrm{mg} / \mathrm{kg}$ BB merupakan dosis yang efektif dalam menurunkan kadar glukosa darah

Hal ini menunjukkan bahwa ekstrak daun pandan wangi dosis 600 $\mathrm{mg} / \mathrm{kg}$ BB dan ekstrakdosis kombinasi (II) $75+300 \mathrm{mg} / \mathrm{kg}$ BB belum maksimal memberikan efek penurunan kadarglukosa darah sama dengan kelompok positif. Sedangkan ekstrak daun sirsak dosis $150 \mathrm{mg} / \mathrm{kg} \quad \mathrm{BB}$, ekstrak dosis kombinasi (I) 150+600 $\mathrm{mg} / \mathrm{kg}$ BB memberikan efek terhadap penurunan kadarglukosa darah. ekstrak daun sirsak dosis $150 \mathrm{mg} / \mathrm{kg} \quad \mathrm{BB}$ merupakan dosis yang efektif dalam menurunkan kadar glukosa darah.

Efek penurunan kadar kolesterol total darah disebabkan senyawa bioaktif yang terkandung dalam ekstrak etanol daun sirsak dan pandan wangi seperti Alkaloid, flavonoid, polifenol, saponin, dan tannin dimana mekanisme kerja didalam tubuh memiliki banyak peran sebagai antioksidan flavonoid bertindak sebagai pereduksi LDL didalam tubuh. Flavonoid juga bekerja menurunkan kadar kolesterol dalam darah dengan cara menghambat kerja (HMG co-A reduktase) enzim 3-hidroksil 3metilglutaril koenzim A reduktase (Ranti. 2013). Tanin dalam menurunkan kolesterol total adalah dengan 
mencegah reabsorbsi dan meningkatkan ekskresi kolesterol. Tanin merupakan antioksidan yang bertindak sebagai anti radikal bebas dan mengaktifkan enzim antioksidan. Tanin juga mencegah oksidasi dari kolesterol LDL, menstimulasi sekresi garam empedu dan membuang kolesterol melalui feses (Lajuck. 2012). Polifenol dapat menurunkan absorpsi kolesterol dan menurunkan sekresi apo-B yang menyebabkan penurunan produksi lipoprotein (Andarwulan. 2012). Saponin dapat berikatan dengan kolesterol pada lumen intestinal sehingga dapat mencegah reabsorpsi kolesterol.Saponin juga dapat berikatan dengan asam empedu sehingga dapat menurunkan sirkulasi enterohepatik asam empedu dan meningkatkan ekskresi kolesterol.Saponin merupakan metabolit sekunder tanaman yang bersifat surfaktan yang dapat berikatan dengan kolesterol dan asam empedu sehingga mencegah absorpsi kolesterol di usus halus.Selain itu saponin mengurangi absorbsi getah empedu dengan membentuk kompleks misel yang tidak dapat diabsorbsi karena berat molekulnya terlalu besar.Saponin dengan kolesterol ternyata juga memiliki reseptor yang sama sehingga dapat terjadi kompetisi reseptor kolesterol pada sel. Saponin dapat mempengaruhi biosintesis kolesterol dihati (Ahmad. 2014).

Efek penurunan kadar glukosa darah disebabkan adanya senyawa bioaktif yang terkandung dalam ekstrak daun sirsak dan pandan wangi seperti alkaloid, flavonoid, saponin, tanin dan polifenol. Alkaloid bekerja dengan menstimulasi hipotalamus untuk meningkatkan sekresi Growth Hormone Releasing Hormone (GHRH), sehingga sekresi Growth Hormone (GH) pada hipofise meningkat. Kadar GH yang tinggi akan menstimulasi hati untuk mensekresikan Insulin-like Growth Factor-1 (IGF-1). IGF-1 mempunyai efek dalam menginduksi hipoglikemia dan menurunkan glukoneogenesis sehingga kadar glukosa darah dan kebutuhan insulin menurun.(Krismawati Agnes . 2007) Senyawa lain yang memiliki aktivitas hipoglikemik adalah flavonoid merupakan senyawa pereduksi yang baik, flavonoid mampu menangkap radikal bebas (ROS/Reactive Oxygen Species atau RNS/Reactive Nitrogen Species) melalui transfer elektron serta penghambatan reaksi peroksidasi.(12Prasetya Hamid. 2013). 
Flavonoid diketahui mampu bekerja secara langsung terhadap sel beta pankreas, dengan memicu pengaktifan kaskade signal cAMP dalam memperkuat sekresi insulin yang disensitisasi oleh glukosa. Senyawa saponin memiliki potensi aktivitas antidiabetes terhadap sekresi insulin yang disebabkan modulasi saluran kalsium dan peremajaan sel $\beta$ pankreas. Saponin memiliki aktivitas sebagai antioksidan, karena memiliki kekuatan mereduksi dan membasmi radikal superoksida dan aktivitas mengikat logam . Tanin diketahui dapat memacu metabolisme glukosa dan lemak sehingga timbunan kedua sumber kalori ini dalam darah dapat dihindar. Selain itu, tanin juga berfungsi sebagai astrigent atau penghelat yang dapat mengerutkan epitel usus halus sehingga mengurangi penyerapan sari makanan dan sebagai akibatnya menghambat asupan glukosa dan laju peningkatan glukosa darah tidak terlalu tinggi. (Afifah. 2013) Polifenol mampu mengurangi stress oksidatif dengan cara mencegah terjadinya rantai pengubahan superoksida menjadi hidrogen superoksida dengan mendonorkan atom hidrogen dari aromatik hidroksil $(-\mathrm{OH})$ polifenol untuk mengikat radikal bebas dan membuangnya dari dalam tubuh melalui sistem eksresi.(Jain Nk, Singhai AK. 2011).

\section{KESIMPULAN}

Berdasarkan hasil penelitian dan pembahasan maka dapat disimpulkan bahwa :

1. Ekstrak etanol daun sirsak memiliki senyawa metabolit sekunder yaitu, alkaloid, flavonoid, polifenol, saponin dan tanin. Sedangkan ekstrak etanol daun pandan wangi memiliki senyawa metabolit sekunder yaitu, alkaloid, flavonoid, polifenol, saponin dan tanin.

2. Ekstrak etanol daun sirsak dan pandan wangi dapat menurunankan kadar kolesterol darah tikus putih jantan yang diberikan pakan tinggi kolesterol dan induksi streptozotocin.

3. Ekstrak daun sirsak (Annona muricata Lin) dan daun pandan wangi (Pandanus amarillyfolius Roxb)memberikan efek terhadap penurunan kadar glukosa darah tikus putih jantan (Rattus norvegicus) yang di beri pakan tinggi kolesterol dan induksi streptozotocin dan tidak menimbulkan toksisitas pada tikus.

4. Kombinasi ekstrak etanol daun sirsak (Annona muricata L) dan daun 
pandan wangi (Pandanus amarillyfolius Roxb) sudah memberikan efek terhadap penurunan kadar kolesterol darah tikus putih jantan (Rattus norvegicus) yang diberikan pakan tinggi kolesterol dan induksi streptozotocin.

5. Ekstrak daun sirsak (Annona muricata) dan daun pandan wangi (Pandanus amarillyfolius) pada dosis tunggal 2 dengan dosis $600 \mathrm{mg} / \mathrm{kg}$ BB dan kombinasi 1 dengan dosis 75 $\mathrm{mg} / \mathrm{kg}+300 \mathrm{mg} / \mathrm{kg}$ BB merupakan dosis yang efektif terhadap penurunan kadar glukosa darah tikus putih jantan (Rattus norvegicus) yang di beri pakan tinggi kolesterol dan induksi streptozotocin.

6. Ekstrak etanol daun sirsak dan pandan wangi dosis yang memberikan efek yang efektif terhadap kadar kolesterol total darah tikus putih jantan yang diinduksi pakan tinggi kolesterol dan streptozotocin yaitu pemberian ekstrak etanol daun sirsak tunggal dosis $150 \mathrm{mg} / \mathrm{kg} \mathrm{BB}$.

7. memberikan efek yang efektif terhadap kadar glukosa darah tikus putih jantan yang diinduksi pakan tinggi kolesterol dan streptozotocin yaitu pemberian ekstrak etanol daun sirsak tunggal dosis $150 \mathrm{mg} / \mathrm{kg} \mathrm{BB}$.

\begin{abstract}
SARAN
Berdasarkan hasil penelitian yang telah diperoleh dalam penelitian ini, maka disarankan pada peneliti selanjutnya perlu dilakukan penelitian yang lebih lanjut untuk pemisahan senyawa aktif ekstrak sirsak (Annona muricata Linn) dan daun pandan wangi (Pandanus amarillyfolius Roxb) sehingga dapat diketahui mekanisme kerjanya untuk menurunkan kadar kolesterol darah dan kadar glukosa darah.
\end{abstract}

\section{DAFTAR PUSTAKA}

Ahmad., 2014.Uji Efek Ekstrak Etanol $70 \%$ Kulit Buah Asam Jawa (Tamarindus indica L.) Terhadap Kadar Kolesterol Total dan Trigliserida Serum Darah Tikus Putih Jantan (Rattus norvegicus) Galur Wistar. Skripsi. Universitas Muhammadiyah Surakarta. Hal: 15

Andarwulan, N. 2012.Senyawa Fenolik pada Beberapa Tanaman Indigenous dari indonesia. Seafact Center. Bogor. Hal. 28 
Badan Penelitian Dan Pengembangan Kesehatan Kementrian Kesehatan RI. 2013. Riset Kesehatan Dasar (Riskesdas 2013). Kementrian Kesehatan Republik Indonesia. Jakarta. Hal 88

Corwin, E. J. 2009. Buku Saku Patofisiologi Edisi Revisi Ke 3. Penerbit BukuKedokteran EGC. Jakarta.

Elis dan Esnawati. 2015. Pengaruh Ekstrak Daun Sirsak (Annona muricata L) Terhadap Glukosa Darah Dan Histologi Pankreas Tikus (Rattus norvegicus) Yang Diinduksi Aloksan. Jurusan Fakultas Sains Dan Teknologi Universitas Islam Negeri (UIN) Maulana Malik Ibrahim Malang. Hal

Guyton, A.C., dan Hall, J.E. 2008. Buku Ajar Fisiologi Kedokteran. Edisi 11.Jakarta: EGC

Gunawan. 2004, “ Farmakognosi Jilid

I', Penerbit Penebar Swadaya,

Jakarta hal 2

Lajuck, P. 2012. Ekstrak Daun Salam (Eugenia Poliantha) Lebih Efektif Menurunkan Kadar Kolesterol Total dan LDL Dibandingkan Statin Pada Penderita Dislipidemia. Tesis.
Program Pascasarjana Universitas Udayana. Denpasar. Hal: 93.

Poedjiadi, A. 2005. Dasar-Dasar Biokimia. Universitas Indonesia, Jakarta.

Premeswari, O M. dan Simon, B. 2014. Uji Efek Ekstrak Air Daun Pandan Wangi Terhadap Penurunan Kadar Glukosa Darah Dan Histopatologi Tikus Diabetes Melitus. Jurnal Pangan Dan Industri Vol. 2. No. 2p. 16-27. FTP Universitas Brawijaya Malang

Ranti, G. C. 2013. Uji Efek Ekstrak Flavonoid Dan Steroid Dari Gedi (Albemoschus manihot) Sebagai Antiobesitas Dan Hipolipidemik Pada Tikus Putih Jantan Galur Wistar. Pharmacon Jurnal Ilmiah Farmasi 2(2). Program Studi Farmasi Fakultas MIPA. Universitas Samratulangi. Manado. Hal. 11

Subroto, A. 2006. Ramuan herbal untuk diabetes mellitus. Penebar Swadaya. Jakarta. Hal. 5, 15

Tandi J, Muthi'ah, Yuliet, Yusriadi. 2016. Efektifitas Ekstrak Daun Gedi Merah Terhadap Glukosa Darah Malondialdehid 8-Hidroksi- 
Deoksiguanosin, Insulin Tikus

Diabetes. STIFA-PM Palu.

Tandi J, Moh Roem, Juliet. 2016. Efek

Nefropotektif Kombinasi Ekstrak

Daun Gedi Merah Dan Daun Daun

Kumis Kucing Pada Tikus Induksi

Etilen Glikol. STIFA-PM Palu

Tandi J. 2017. Pola Penggunaan Obat

Pada Pasien Penyakit Hati Yang

Menjalani Rawat Inap Dirumah

Sakit Daerah Undata Palu. Jurnal

Pengembangan Sumber Daya

Insani. Vol. 2. No. 2. Hal. 218

Tandi, J., Rizky M., Mariani R., Alan F. 2017. Uji Efek Ekstrak Etanol Daun Sukun (Artocarpus altilitis (Parkinson Ex F.A Zom) Terhadap Penurunan Kadar Glukosa Darah, Kolesterol Total, dan Gambaran Histopatologi Pankreas Tikus Putih Jantan (Rattus norvegicus) Hiperkolesterolemia Diabetes. Jurnal Sains dan Kesehatan. Vol.1 No.8. Hal: 384-396. p-ISSN: 23030267, e-ISSN: 2407-6082

TandiJoni, Andika

Lande, Yusriadi,Ririen

Hardani.2017.Uji Efek Antidiabetes

Ekstrak Etanol

Daun

Bugenvil(Bougainvillea spectabillis
Willd) Terhadap Penurunan Kadar

Glukosa Darah Tikus Putih Jantan (Rattus norvegicus)

Hiperkolesterolemia-

Diabetes.(STIFA-PM Palu).

Wulandari, Ririn L,Susilowati, Sri dan Asih, Murnik. 2012. Pengaruh Kombinasi Ekstrak Etanol Daun Sirsak (Annona Muricata L.) Dan Simvastatin Terhadap Kadar Kolesterol Total Dan Low Density Lipoprotein (LDL) Tikus Yang Diinduksi Pakan Tinggi Lemak. Fakultas Farmasi, Universitas Wahid Hasyim Semarang.

World Health Organization (WHO). 2016. The World Health Report 2016

Yani, M. 2015. Mengendalikan Kadar Kolesterol Pada Hiperkolesterolemia. Jurnal Olahraga Prestasi, Volume 11, Nomor 2. Prodi Ilmu Keolahragaan. Universitas Yogyakarta. Halaman 2 